\title{
Perancangan Aplikasi sebagai Wadah Penggemar Kopi di Indonesia
}

\author{
Brillian Foedinatha ${ }^{*}$, Deddi Duto Hartanto ${ }^{2}$ \\ Program Studi Desain Komunikasi Visual, Fakultas Seni dan Desain \\ Universitas Kristen Petra, Jl. Siwalankerto No.121-131, Surabaya \\ *Penulis korespondensi; E-mail:e12170037@john.petra.ac.id
}

\begin{abstract}
Abstrak
Di Indonesia budaya minum kopi sudah ada semenjak jaman VOC (Vereenigde Oost-Indische Compagnie) datang ke Indonesia. Budaya tersebut terus berkembang hingga saat era kopi memasuki gelombang ketiga yang dikenal dengan Third Wave Coffee. Pada era ini, terjadi perubahan sudut pandang tentang kopi yang tidak hanya sebatas komoditas untuk diminum namun sudah menjadi seni dan pengetahuan dari hulu ke hilir hingga kopi disajikan pada cangkir. Adanya kopi gelombang ketiga dan terlahirnya Kopi spesial membuat komunitas terbentuk di Indonesia, bahkan lahirnya asosiasi kopi di Indonesia melambangkan perkembangan kopi di Indonesia. Dengan adanya komunitas yang terbentuk, belum ada media dengan wadah online yang memberi fasilitas untuk para penggemarnya. Oleh karena itu, Kavi coffee app hadir untuk menyelesaikan masalah sebagai wadah interaktif online untuk para penggemar kopi di Indonesia.
\end{abstract}

Kata Kunci: Indonesia, Kopi, Spesial, Komunitas, Wadah, Online.

\begin{abstract}
In Indonesia, the culture of drinking coffee has existed since the VOC (Vereenigde Oost-Indische Compagnie) era came to Indonesia. This culture continues to develop until the time when the coffee era enters its third wave known as Third Wave Coffee. In this era, there has been a change in the perspective of coffee which is not only a commodity to be drunk but has become an art and knowledge from upstream to downstream until coffee is served in cups. The existence of Third Wave Coffee and the birth of specialty coffee has formed a community in Indonesia. Even the birth of a coffee association in Indonesia symbolizes the development of coffee in Indonesia. With the community being formed, there are no media with an online platform that provides facilities for its fans. Therefore, the Kavi coffee app is here to solve problems as an interactive online platform for coffee fans in Indonesia.
\end{abstract}

Keywords: Indonesian, Coffee, Specialty, Community, Platform, Online.

\section{Pendahuluan}

Indonesia merupakan salah satu produsen kopi terbesar di dunia. Menurut Indonesia baik.id Indonesia adalah negara penghasil biji kopi terbesar keempat di dunia setelah Brazil, Vietnam dan Kolombia dengan produksi ratarata sebesar 639 ribu ton per tahun atau sekitar $8 \%$ dari produksi kopi dunia. Komposisi produksi kopi Indonesia adalah $72,84 \%$ kopi jenis robusta dan $27,16 \%$ kopi jenis arabika (Nurhanisah, 2019). Dengan adanya kelimpahan tersebut, pebisnis Food and Beverage melihatnya sebagai peluang dan menjadikannya tempat meraih keuntungan dengan menciptakannya café dan coffee shop. Budaya minum kopi sejatinya sudah ada di Indonesia sejak zaman Belanda menjajah, pada masa itu VOC membawa kopi ke Indonesia. Saat ini setelah berkembangnya industrimakanan dan minuman di Indonesia, kopi bukan hanya untuk kebutuhan konsumsi biasa melainkan kopi sekarang dibuat menjadi ladang bisnis dan hobi.

Dengan berdampingan bisnis kopi dengan teknologi, banyak inovasi-inovasi yang bermunculan dan inovasi tersebut mendorong pesat bisnis industri kopi dan hal ini mendorong kemunculan third wave coffee di Indonesia. Third wave coffee adalah sebuah gelombang dengan melihat kopi tidak hanya komoditas untuk dikonsumsi melainkan kopi memiliki proses yang cukup rumit yang mulai di apresiasi dan banyak dipelajari. Pada gelombang ini, kopi mulai memiliki kategori dan kelas yang terbagi pada biji kopidan melahirkan julukan 
yaitu specialty coffee. Dikarenakan third wave coffee, pengetahuan konsumen terhadap kopi semakin melonjak dan membuat konsumen ingin mengetahui bagaimana cara seduhnya, cara roasting, dan asal dari biji kopi tersebut. Adanya aktivitas-aktivitas tersebut menyebabkan terbentuknya sebuah komunitas untuk penggemar kopi, dan hal tersebut sebagai buktinyadapat dilihat dari terbentuknya SCAI (Specialty CoffeeAssociation of Indonesia).

COVID-19 di Indonesia memunculkan gaya hidup baru yang diwajibkan oleh pemerintah untuk dipatuhi. Social Distancing, protokol baru yang dikeluarkan pemerintah Indonesia membuat masyarakat harus menjaga jarak dan mengurangi pertemuan secara fisik dan tempat-tempat ramai. Dikarenakan virus COVID19 mudah menyebar, pemerintah menyarankan untuk masyarakat melakukan segala aktivitas secara virtual, kebijakan ini muncul untuk mengurangi tingkat penyebaran yang terjadi di Indonesia.

Aktivitas yang dilakukan saat berada di sebuah coffee shop menjadi terdampak dan terbatas. Sebuah kebiasaan seperti momen sharing, belajar menyeduh, berkenalan dengan barista atau roaster untuk bertukar informasi menjadi terbatas. Dikarenakan adanya pandemi dan sistem new normal membuat komunitas kopi menjadi kehilangan wadahnya, "kedai sekarang jadi tidak seramai dulu sebelum pandemi, padahal dulu saat ramai bisa dengan mudah kita untuk saling sharing dan tukar informasi mengenai perkopian." (Rian 2020). Dikarenakan kekompleksan dalam sebuah kopi, diperlukannya komunikasi yang banyak di dalam industri tersebut. Tidak dapat mengandalkan salah satu peran dalam industri ini, mulai dari petani, roaster, hingga brewer semuanya menjadi satu rantai yang saling berhubungan. "Coffee shop adalah muara terakhir sebelum secangkir kopi mendarat ke atas mejamu. Sebelumnya, kopi telah melewati banyak tangan yang memprosesnya satu per satu dengan passion dan antusiasme yang menjadikannya begitu istimewa" (Treisna, 2015). Tidak hanya kesulitan yang terjadi pada sebuah kedai, kesulitan itu juga tampak pada sebuah jalur dalam industri kopi seperti hubungan antara petani kopi dan juga roaster kopi. Menurut rian selaku roaster independen dan juga barista di coffee shop Oak Tree "Susah sekarang buat dapat green beans yang kita mau, berhubungan langsung dengan petani kopi di lapangan susah karena masa pandemi, jadi untuk supply green beans yang kita inginkan lebih sulit” (Rian, 2020).

Berdasarkan uraian masalah yang dituliskan diatas, adanya peluang yang dapat dilakukan. Dengan keberadaan teknologi, keinginan berkumpul bersama di sebuah café maupun coffee shop, belajar bersama komunitas, dapat tetap dilakukan walau memiliki keterbatasan jarak. Melalui pembuatan aplikasi wadah interaksi penggemar kopi online, diharapkan terbentuknya sebuah wadah untuk penggemar kopidan secara skala besar dapat memperlancar industri dan komunitas kopi.

Terdapat peluang yang dapat dilakukan berhubungan keberadaan teknologi, keinginan berkumpul bersamadi café maupun coffee shop, belajar bersama komunitas, dapat tetap dilakukan walau memiliki keterbatasan jarak. Melalui pembuatan aplikasi wadah interaksi penggemar kopi online, diharapkan terbentuknya sebuah wadah untuk penggemar kopi dan secara skala besar dapat memperlancar industri dan komunitas kopi. Dalam perancangan aplikasi, diharapkan pengguna pada aplikasi ini bisa melakukan branding diri dalam dunia kopi selain itu diharapkan pengguna dapat menemukan informasi dan edukasi seputar kopi menjadi lebih mudah.

\section{Metode Penelitian}

Terdapat dua data yang dibutuhkan yaitu data primer dan juga data sekunder. Data primer yang akan diperoleh adalah bagaimana perilaku penggemar kopi yang sering berkumpul bersama komunitas/teman untuk eksplorasi kopi. Terkhususnya pada saat kehidupan baru new normal yang membatasi interaksi. Data sekunder yang akan diperoleh adalah mengenai visualisasi, brand, yang sesuai untuk target, konten dan juga fitur yang tepat untuk memberi fasilitas kepada aplikasi.

Untuk metode pengumpulan data dari penelitian tersebut, pengumpulan data dilakukan dengan cara melakukan wawancara Bersama pemilik coffee shop, barista, roasters dan juga Home brewer. Selain itu dilakukan juga eksplorasi analisa visual pada internet untuk menentukan dan memilih tone and manner yang tepat bagi target audience. Metode yang digunakan untuk analisis data adalah metode deskriptif kualitatif. Data-data yang ada diseleksi dan dianalisis, kemudian ditarik kesimpulannya denganmetode $5 \mathrm{~W}+1 \mathrm{H}$, misal dengan mencari data Apa hal yang digemari komunitas terhadap berkumpul di café/coffee shop, siapa yang ter- 
tarik dalam Third wave coffee, kapan waktu yang tepat untuk komunitas berkumpul dan bertukar cerita, mengapa penggemar kopi perlu wadah online untuk berinteraksi, dan bagaimana komunitas dapat menjangkau/ memperbesar grupnya.

Khalayak sasaran pada perancangan adalah sebagai berikut:

Geografis : Bertempat tinggal di Indonesia, kawasan Urban hingga Sub-urban

Demografis : Berusia 17 hingga 32 tahun, dengan jenis kelamin pria atau wanita dan berlatar, mahasiswa atau wiraswasta dengan status SES B-A

Psikografis : Sosialisasi tinggi, independen, jiwa eksplorasi tinggi, modern, peka terhadap teknologi, influence.

Behavior : Suka berkumpul bersama teman, gemar bermain media sosial, suka bertukar cerita, gemar minum kopi (frekuensi dalam hitung minggu dapat mengkonsumsi kopi minimal 3 kali).

\section{Hasil dan Pembahasan}

Meminum kopi awal mulanya hanya sebatas minuman sehari hari yang dikonsumsi karena membutuhkan zat kafein di dalamnya agar tetap terjaga dan siap sebelum memulai kegiatan. Karena adanya era globalisasi dan inovasi pada dunia kopi, hadir kopi dengan campuran krim atau bahan lainnya yang bertujuan membawa kopi menjadi hidangan yang lebih menarik. Perubahan pada kopi tersebut dikenal dengan perubahan gelombang pertama dan gelombang kedua pada dunia kopi.

Masyarakat mengenal kopi sebagai minuman berwarna gelap yang diseduh dari bubuk biji kopi. Ethiopia adalah tempat kelahiran kopi. Faktanya, istilah bahasa Inggris biji kopi mungkin berasal dari Kata Ethiopia bun, untuk kopi, dan Kaffa, daerah di mana biji arabika adalah tanaman asli (Freeman et al., 2012). Biji kopi dapat diperoleh dari buah ceri yang tumbuh disemak tersebut, Setelah dipanen buah-buahkopi yang dipetik kemudian dibawa ke tempat pengolahan/penggilingan untuk memisahkan biji dengan kulit dagingnya. Biji inilah yang kemudian akan dikeringkan agar tetap aman disimpan sebelum dijual ke pasar. Idealnya, kopi memiliki tingkat kelembaban alami sekitar 60\%, namun ia dikeringkan sampai kelembapannya hanya berkisar sekitar $11-12 \%$ saja. Tujuannya supaya biji kopi itu tidak terlalu lembap lalu membusuk ketika "menunggu" dijual" (Masdakaty, 2015). Biji kopi yang sudah diproses, hasil akhirnya berupa biji hijau atau yang dikenal dengan green bean yang nantinya akan disangrai dan menjadi biji kopi siap digiling dan diseduh.

Kopi membutuhkan alur proses yang cukup Panjang, mulai dari petani hingga mencapai kepada tangan barista dan penyeduh. Proses dalam pembuatan kopitidak dapat diremehkan dikarenakan prosesnya yang cukup sulit. Ada beragam metode dan cara dalam mengolah biji kopi. Salah satu peranan penting dalam pengolahan kopi pertama berada pada petani kopi.

Petani kopi adalah peranan awal dari industri kopi, petani kopi awalnya harus memilih jenis kopi seperti apa yang akan mereka tanam robusta kah atau arabika. Selain itu petani kopi tak bisa menanam kopi di mana saja karena hanya lahan-lahan di ketinggian tertentu saja yang bisa ditanami kopi (Treisna, 2015). Petani kopi juga perlu memperhatikan bagian-bagiankecil dan detail pada tumbuhan kopi seperti saat proses pemetikan biji kopi, pemetikan ceri kopi mempengaruhi kualitas biji kopi, bayangkan jika ceri kopi bercampur ada yang merah dan ada juga yang hijau. Tentu karakter rasa nantinya akan bercampur, menyebabkan kualitas dari biji kopi menurun (Aizeindra, 2019).

\section{Green Coffee Bean Buyer}

Green coffee bean buyer dikenal sebagai pembeli kopi biji mentah, peran green coffe bean buyer tidak mudah dikarenakan banyaknya faktor yang harus diperhatikan dalam pembelian biji hijau kopi. Green buyer biasanya akan melakukan perjalanan dari satuperkebunan kopi ke perkebunan lainnya untuk melihat kualitas green bean dari para petani. Mereka memilih biji kopi mentah terbaik, melakukan banyak sekali proses cupping untuk mendapatkan kopi yang terbaik juga (Treisna, 2015). Ada juga, coffee buyer merangkap menjadi seorang konsultan untuk meningkatkan kualitas produksi. Maka sudahseharusnya menjadi seorang coffee buyer harus mengerti keseluruhan menyangkut budidaya tanam kopi dan lainnya (Aizeindra, 2018).

\section{Roastery}

Seorang Roaster memegang kunci utama dalam menciptakan rasa dan karakter pada biji kopi sampai dalam cangkir. Peran ini juga tidak mudah dan perlu banyak aspek yang harus diperhatikan dalam melakukan roasting. Banyak specialty coffee roastersyang harus mengalami beberapa kali percobaan, proses gagal, dan trial 
and error dulu sebelum mendapat pola roasting terbaik untuk masing-masingkopi yang mereka sangrai (Masdakaty, 2015).

\section{Barista}

Barista sering dijumpai pada sebuah café, coffee shop, dan juga mungkin dalam sebuah restoran dan hotel. Barista memiliki peran untuk menuangkan ilmunya dalam menyeduh kopi bagi konsumennya. Peran barista secara tradisional adalah menyiapkan dan menyajikan minuman kepada konsumen namun perihal kopi menjadi lebih kompleks saat ini dan pelanggan lebih tertarik pada barista yang cerdas dan berpengalaman (Colonna Dashwood \& Jay, 2017).

\section{Budaya minum kopi di Indonesia}

Budaya minum kopi di Indonesia sudah menjadi lifestyle di era modern ini. Dalam penelitian terdahulu dengan judul "Fenomena Coffee Shop Sebagai Gejala Gaya Hidup Baru Kaum Muda" dituliskan Kopi kini telah menjadi bagian dari gaya hidup, khususnya bagi mereka yang tinggal di kota besar, secara spesifik Jakarta dan Yogyakarta yang menjadiperhatian kajian ini (Elly, 2012, p.5). Sebenarnya tren dalam kopi di Indonesia sudah dikenal cukup lama, Pada akhir abad 16 saat Indonesia masih di bawah jajahan Belanda, VOC membawa tanaman kopi Arabika kedalam negara ini (Devvany, Ivana, 2017) dan tradisi "ngopi" di Indonesia sudah ada karena pengaruh budaya luar dan terbawa hingga saat ini. Perilaku mengonsumsi kopi sekarang sudah menjadi budaya global yang ditandai oleh masuknya kedai kopi Starbucks yang merupakan salah satu kedai kopibersifat franchise yang berasal dari Amerika Serikat (Solikatun, Tri, Demartoto, 2015). Bahkan saat ini berbudaya minum kopi sudah mulai berkembang, mulai dari yang awalnya hanya sebatas berkumpul dan menikmati kopi, saat ini kopi menjadi perihal yang menarik untuk dipelajari. Menurut Niki, Minum kopi bukan hanya sekedar menikmati saja tetapi menambah pengetahuan tentang bagaimana cara membuat kopi yang enak, juga mengetahui berasal dari daerah manasaja kopi yang minum dan jenis kopi apa saja yang diminum (Andani, 2020). Terdapat hal tersebut, industri kopi terus berkembang dikarenakan komunitas yang terbangun dari konsumennya.

\section{Multimedia}

Multimedia, secara etimologis multimedia berasal dari bahasa Latin, yaitu dari kata "multi" yang berarti banyak; bermacam-macam dan "medium" yang berarti sesuatu yang dipakai untuk menyampaikan atau membawa sesuatu (wijaya, 2014). Dan pada dasarnya media tersebut dibagi menjadi dua kategori, multimedia linear dan juga multimedia Interaktif. Multimedia linear adalah suatu multimedia yang tidak dilengkapi dengan alat pengontrol yang dapat dioperasikan oleh pengguna (Wijaya, 2014) ada juga media linear sebagai contohnya TV yang mengikuti program jam tayang sesuai keinginan pusat sehingga penonton tidak dapat mengontrolnya (Morel, 2015). Menurut penelitian sebelumnya yang berjudul "Hyakugo sebagai multimedia interaktifpembelajaran Kanji N5" multimedia interaktif adalah sebuah perantara untuk menyampaikan sebuah informasi kepada user media tersebut yang melibatkan user langsung dalam pengoperasian mediatersebut secara aktif karena disertai pengontrol agar user dapat mengatur penerimaan informasi dalam media tersebut (Somantri, 2011, p.17) ada juga disebutkan, Multimedia interaktif adalah metode komunikasi dengan menggunakan program yangmemiliki output berdasarkan input pengguna, yang dimana input pengguna akan mempengaruhi hasil output program tersebut (Dhir, 2019).

\section{Aplikasi}

Salah satu media interaktif pilihan penulis adalah aplikasi. Aplikasi atau yang dikenal dengan mobile application perangkat lunak ini dimiliki oleh beberapa perangkat seperti smart phone, tablet dan lain-lain. Aplikasi mobile umumnya serupa dengan software yang berada di PC namun memiliki keterbatasan akses dan fitur dikarenakan bentuknya yang kecil (What Is a Mobile Application?, 2020). Aplikasi dikarenakan praktis dan kemudahan dalam menggunakannya membuat perangkat lunak ini menjadi peran pembantu yang sangat baik, aplikasi mobile telah menjadi sangat menyebar dalam beberapa waktu terakhir (Holl \& Elberzhager, 2019). Aplikasi yang umum dikenal oleh banyak orang dijalankan dengan platform seluler berbasis Android, iOS, dan windows. Pada smartphone saat ini yang mendominasi adalah Android dan iOS, Dimulai dari sebuah data yang mengatakan bahwa pengguna aplikasi mobile terutama Android dan iOS, jauh lebih banyak dari pengguna aplikasi platform lain. Dari data tersebut, perusahaan pengembang aplikasi berlomba-lomba untuk membangun aplikasi mobile (Radiegtya, 2018). Aplikasi memiliki beberapa keunggulan di antaranya, User Interface dan User Experiece (UI/UX) aplikasi 
seluler bisanya cukup menarik dan sangat mudah digunakan, ada beberapa aplikasi yang bisa digunakan tanpa harus terkoneksi internet, Pengguna atau user dapat mengakses aplikasi dimana saja melalui gadgetnya (Guntoro, 2020). Salah satu jenis aplikasi yang terkenal di Indonesia adalah aplikasi sosial media, Sebagai negara yang terletak di wilayah Asia Pasifik, Indonesia menjadi bagian dari 4,3 milyar total penduduk di wilayah ini. Separuh lebih dari populasitersebut, sekitar 56\% atau 2,42 milyar di antaranya sudah mendapatkan akses internet. Dan tepat separuhnya, yakni sekitar 2,14 milyar penduduk telahmenggunakan sosial media (Ramadhan, 2020). Hal ini menunjukkan bahwa Indonesia adalah masyarakat yang menggemari social network dan memiliki jiwa sosial tinggi.

\section{Target Market}

Dalam target market yang dipilih oleh penulis adalah generasi Millennial, dengan status ekonomi sosial A- B didaerah perkotaan Indonesia. Menurut Elwood Carlson (2008), generasi millennial adalah merekayang lahir dalam rentang tahun 1983 hingga 2001 (Indah, et.al., 2018, p.14) dalam penentuan target market berikut, penulis memilih generasi millennial dikarenakan beberapa fakta dan data yang dikumpulkan.

\section{Psikografis Millennial}

Diambil dari buku dengan judul "Profil Generasi Millennial Indonesia" yang diterbitkan oleh kementerian pemberdayaan perempuan dan perlindungan anak menuliskan bahwa kaum millennial memiliki keunikan, salah satu ciri utama generasi millennial ditandai oleh peningkatan penggunaan dan keakraban dengan komunikasi, media, dan teknologi digital (Indah, et.al., 2018, p.14) dengan data dan fakta yang dituliskan dalam buku tersebut, tergambarkan kecocokan psikografis dari rancangan aplikasi wadah interaksi pecinta kopi online, yang dimana aplikasi ini melibatkan adanya komunikasi, media dan teknologi. Ada juga ditambahkan dalam buku tersebut bahwa karena dibesarkan oleh kemajuan teknologi, generasi millennial memiliki ciri-ciri kreatif, informatif, mempunyai passion dan produktif (Indah, et.al., 2018,p.18).

Dengan memiliki sifat tersebut, generasi millennial membutuhkan kemajuan teknologi seperti smartphone untuk mendukung keseharian mereka. Dimana dalam hal tersebut penulis mendapat kesimpulan bahwa smartphone adalah salah satu perangkat yang selalu berada di genggaman generasi millennial dan konten atau aplikasi yang berada dalam platform tersebut sangat berpengaruh dalam keberlangsungan hidup mereka. Tingginya tingkat sosialisme dalam generasi millennial juga tertulis pada artikel infografis indonesiabaik.id, generasi millennial juga memiliki perilaku senang berwisata. 1 dari 3 millenial di Indonesia liburan minimal 1 kali dalam setahun. Di sisi lain, millennial terhitung gemarberbagi, peduli dan responsif terhadap masalah sosial (Nurhanisah, 2019).

Mengenai peduli dan responsif generasi millennial tersebut didukung oleh artikel IDN times yang mengatakan generasi muda menghabiskan banyak waktu untuk berselancar di dunia maya dengan perangkat pintarnya. Dari situlah mereka dihujani banyak informasi di seluruh dunia (Wijayanti, 2020). Dengan ciriciri sifat sosial dari generasi millennial yang didapat dari sejumlah artikel di atas, dapat ditarik sebuah kesimpulan bahwa aplikasi wadah interaksi pecinta kopi online dapat diterima dengan mudah olehgenerasi millennial. Pada kasus ini terlihat juga bahwa industri kopi tahun terakhir ini marak pada generasi millennial, tren minum kopi sudah menjadi bagian dari gaya hidup masyarakat Indonesia, khususnya kalangan generasi millennial, untuk mendukung produktivitas saat bekerja maupun saat berkumpul bersama teman. Hal ini terlihat dari semakin banyaknya coffee shop yang muncul di kota-kota besar di Indonesia (Handayani, 2018).

\section{Milenial dalam Industri Kopi}

Di Indonesia dalam target market yang penulis pilih, penulis menemukan beberapa respon dari ahli-ahli dan jurnalis tentang partisipasi dan dampak millennial terhadap industri kopi di Indonesia, wakil ketua umumasosiasi eksportir dan industri kopi Indonesia Pranoto soenarto mengatakan pesatnya pertumbuhan kopi di tanah air turut berdampak pada lahirnya petani kopi, khususnya dikalangan generasi millennial (antaranews.com, 2019) ditambahkannya lagi, Pranoto soenarto berkata "Bisa dilihat dari menjamurnya kedai kopi dan pusat roaster kopi mikrodi hamper seluruh kota besar di Indonesia. Tentunya, diharapkan akan banyak anak muda yang beralih menjadi petani kopi”. Ada juga, $48 \%$ dari penduduk yang berusia 18 24 tahun, dan $60 \%$ dari penduduk yang berusia 25-39 tahun, menikmati kopi setiap harinya. Tren ini sepertinya juga akan terusmenanjak, mengingat terjadi pergeseran budaya minum 
kopi, mengingat millennial mengembangkan kebiasaan minum kopi sedari umur 15 tahun (Satria, 2018).

Tidak sebatas dalam penikmat kopi saja, generasi millennial juga memiliki keinginan yang kuat dalam berbisnis di industri ini, menurut pemilik kedai kopi Teman Baik BSD, Ayu Aulia, untuk memulai bisnis kopi kekinian tidak harus mempunyai modal yang besar, cukup dengan uang Rp 17 juta. Siapa pun bisa memulainya terutama kaum millennial yang baru ingin memulai bisnis (Cahyani, 2019). Ditambahkan lagi dari narasumber founder Sekopi, Rudi ersan mengatakan "Bisnis ini untungnya lumayan. Ada potensi Rp 1000 triliun dalam bisnis kreatif kopi di dunia dari hulu sampai hilir. Millennial tinggal memilihnya" (dalam indozone, 2019). Dengan modal yang dapat dikategorikan terjangkau bagi generasi millennial dan keuntungan yang besar, hal ini membuat generasi millennial semakin tergoda dalamterjun kedunia industri kopi.

\section{Behavior Millennial pada Coffee Shop / Café}

Coffee shop atau café yang awalnya memiliki fungsi sebagai tempat makan dan minum telah bergeser di generasi millennial. Generasi millennial membuat cafe atau coffee shop sebagai tempat untuk berkumpuldan bersantai, hal ini dituliskan juga dalam artikel dari line today bahwa fungsi cafe memang kini bukan hanya untuk tempat makan dan minum, melainkan sebagai wadah aktivitas tertentu seperti bersosialisasi, menunggu sesuatu, bekerja, berdiskusi, atau aktivitas pembunuh waktu lainnya (Keepo.me, 2018) tidak sebatas artikel tersebut, dalam artikel yang berjudul Fenomena coffee shop di kalangan remaja menuliskan coffee house (coffee shop) sebagai tempatuntuk mengerjakan tugas kuliah, rapat, atau berdiskusi karena dengan meminum kopi dapat meningkatkan konsentrasi dan fokus seseorang (Nurikhsan, Indrianie, \& Safitri, 2019).

Aktivitas-aktivitas tersebut banyak dilakukan oleh generasi millennial dikarenakan sifat dasar sosialisasi yang cukup tinggi. Dilansir dari artikel IDN menuliskan millennial lebih suka menghabiskan uang untuk mendapat pengalaman tertentu dibanding menabung untuk menambah asset (Wijayanti, 2020). Tidak sebatas untuk berkumpul bersama teman, beberapa dari pengunjung coffee shop datang untuk memahami kopi lebih dalam. Kata Luh putu murti, "Kami tidak kaku lebih banyak belajar rasa kopi dari pelanggan. Kadang mereka pelanggan coba disuruh buat kopi dengan rasa berbeda" (dalam JawaPos.com, 2019). Dikarenakan kompleksnya proses dari sebuah kopi, mulai dari menyangrai, menyeduh hingga pemilihan biji kopi membuat millennial menjadi tertarik ingin mempelajari lebih dalam ilmu kopi pada ahlinya. Peristiwa ini dapat dilihat dari perubahan sudut pandang profesi barista yang dahulunya profesi ini tidak terlalu digemari hingga saat ini menjadi profesi yang keren, Barista adalah profesi yang berkutat di balik bar dan biasanyamenyajikan minuman seperti kopi. Turunan dari profesi bartender ini dulunya adalah profesi yang sangat di pandang sebelah mata. Namun, beberapa tahun belakangan profesi barista semakin naik daun dan menjadi profesi yang diminati dikalangan anak muda indonesia. (hidayah, 2020).

\section{Tinjauan Fakta Pasar}

Belakangan ini Indonesia sedang dilanda tren minum kopi, fenomena ini dapat dilihat dari peningkatannyajumlah produksi kopi dan juga jumlah data kedai kopiyang buka di Indonesia. Toffin mengatakan, "Hasil riset Toffin bersama Majalah Mix menunjukkan jumlah kedai kopi di Indonesia pada Agustus 2019 mencapai lebih dari 2.950 gerai, meningkat hampir tiga kali lipat dibandingkan pada 2016 yang hanya sekitar 1.000" (Toffin, 2020). Selain itu, Ekspor kopi Indonesia diperkirakan akan meningkat 400.000 karung berdasarkan produksi yang lebih tinggi dan harga yang kompetitif untuk varietas Robusta dan Arabika. Konsumsi dalam negeri yang meningkat diharapkan dapat mendorong permintaan biji lokal dan mengurangi impor (GAIN, 2019). Peningkatan yang pesat tersebut tidak hanya dapat dirasakan oleh pebisnis besar namun juga pebisnis kecil yang ingin mencoba meraih keuntungan dalam momen tersebut. Banyaknya persaingan dalam industri kopi ini menstimulasi kreativitas dari para pebisnis di industri kopi sehingga terciptanya café dan coffee.

\section{Faktor Trend}

Kopi menjadi tren belakangan ini dikarenakan revolusi yang terjadi pada industri kopi. Revolusi tersebut tampak pada masuknya budaya kopi di Indonesia setelah itu adanya industri 4.0 yang juga berpengaruh dalam industri kopi yang menyebabkan munculnya third wave kopi dan menciptakan specialty coffee. 


\section{Budaya "Ngopi Kekinian"}

Tidak dapat dipungkiri bahwa Indonesia merupakan negara keempat penghasil kopi terbesar di dunia, hal tersebut justru membuat Indonesia memiliki budaya minum kopi. Dalam penelitian sebelumnya yang berjudul Perilaku konsumsi kopi sebagai budaya masyarakat: Studi Fenomenologi pada Peminum Kopi di Kedai Kopi Kota Semarang, menuliskan perilaku konsumsi peminum kopi yang berkaitan dengan budaya masyarakat konsumsi. Di mana budaya konsunsi kopi ini biasanya dilakukan masyarakat di warung-warung kopi. Tetapi seiring dengan perkembangannya istilah baru untuk menyebut warung kopi dengan sebutan kedai kopi (Solikatun, Drajat, \& Argyo, 2015).

Dalam penelitian tersebut juga menuliskan bahwa budaya minum kopi berasal dari budaya luar, dimana Indonesia mengalami globalisasi dan menerima budaya tersebut masuk ke Indonesia. Dikarenakan adanya budaya minum kopi ini, sebuah kedai, café, atau warung menjadi tempat berkumpul dan bersosialisasi.

Apakah anda peminum kopi?

60 responses

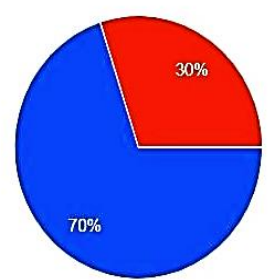

Gambar 1. Data Peminum Kopi

Pada era ini, millennial memasuki gelombang ketiga pada kopi atau yang dikenal dengan third wavecoffee. Dilansir dari majalah Otten, Third Wave Coffee ditandai dengan mulai tertariknya para peminum kopi terhadap kopi itu sendiri. Baik itu asalmuasal bijinya, prosesnya sampai kepada penyajian sebelum kopi tersebut sampai ke tegukan (Yuliandri, 2015). Pada gelombang ketiga ini, kopi mulai dihargai kemunculannya bahkan menganggap minuman kopi adalah sebuah seni, dimulai dari asal atau yang dikenal sebagai origin, lalu proses yang dilalui kopi tersebut, hingga metode penyeduhan pada kopi. Kemunculan dari Third wave coffee di Indonesia disambut baik oleh millennial, hal ini tampak pada munculnya macam-macam kopi di Indonesia dengan daerah-daerah yang lebih spesifik, Cirinya adalah mulai bermunculan Single Origin Coffee dengan nama daerah, varietasnya, proses pengolahan, hingga waktu roasting. Jika anda penikmat kopi, anda akan semakin bisa membedakan antara kopi robusta dan kopi arabica (Mustofa, 2019)imbuhnya, semua menawarkan cita rasa dan keunikan masing-masing. Anda mungkin akan menemui kopi yang memiliki rasa mirip apel, asam wine, kacang, hingga rasa apricot.

Dengan masuknya third wave coffee di Indonesia disamping era millennial berlangsung membuat generasi tersebut menjadi tertarik dikarenakan jiwa penasaran mereka yang begitu tinggi dan rasa ingin tahu. Tidak bisa dipungkiri bahwa tren dan media sosial membuat third wave coffee semakin dikenal oleh generasi milenial. Kehadiran dari third wave coffee menimbulkan perubahan standar pada penilaian kopi. Kopi yang dulunya sekedar dinikmati sekarang melewati beberapa proses yang memiliki standar penilaian yang cukup rumit. Mulai dari kualitas pada green beans, Teknik proses pada biji kopi, menimbulkan penilaian specialty dalam industri kopi. Specialty coffee adalah kopi yang mempunyai kualitas bagus, baik rasa mau pun aroma dengan standar ukur cupping test dan tentunya diproses dengan ketentuan khusus (aizeindra, 2019) Selain dari awal mula biji kopi yang melewati standarisasi yang rumit, teknikteknik dalam menyeduh kopi juga mulai beragam dan dikenal oleh banyak orang terkhususnya barista. Teknik yang beragam ini juga menciptakan perbedaan rasa dan aroma pada kopi yang akan diseduh, dikarenakan Teknik dan alat yang beragam, tidak menutup kemungkinan dengan biji kopi yang sama asalnya danprofil sangrainya akan menghasilkan rasa dan aroma yang berbeda.

\section{Faktor Needs / Insight}

Seperti yang tertulis dalam latar belakang masalah, dikarenakan pandemi dan social distancing, café dan coffee shop mengalami penurunan dalam kunjungan. Dikarenakan hal tersebut, penggemar kopi menjadi kehilangan tempat/ wadah untuk melakukan aktivitas yang mereka gemari, mulai dari sharing, belajar tentang kopi, berkumpul bersama teman, dan lain sebagainya. Dari data dan fakta yang penulis temukan dan tuliskan pada poin dan bab sebelumnya, terlihat bahwa konsumen, generasi millennial, penggemar kopi, membutuhkan wadah atau tempat interaksi yang dapat digunakan dengan tidak memiliki permasalahan dengan lokasi / tempat fisik. Dikarenakan pandemi yang terjadi, gaya hidup di Indonesia menjadi berubah, New normal mem- 
bawa kebiasaan yang baru pada penggemar kopi sehingga membuat para penggemar kopi kekurangan atau bahkan kehilangan fasilitas untuk bersosialisasi kembali.

\section{Faktor Bisnis / Ekonomi dan Opportunity}

Dalam faktor pertanian pada kopi, peningkatan produksi kopi terus menaik mulai dari tahun 2016 hingga 2020, Berdasarkan Pusat Data dan Sistem Informasi Pertanian Kementerian Pertanian konsumsi kopi nasional pada 2016 mencapai sekitar 250 ribu ton dan tumbuh $10,54 \%$ menjadi 276 ribu ton. Konsumsi kopi Indonesia sepanjang periode 2016-2021 diprediksi tumbuh rata-rata $8,22 \% /$ tahun. Pada 2021, pasokan kopi diprediksi mencapai 795 ribu ton dengan konsumsi 370 ribu ton, sehingga terjadi surplus 425 ribu ton (2021, Konsumsi Kopi Indonesia Diprediksi Mencapai 370 Ribu Ton (Databoks, 2018). Kenaikan ini menyebabkan harga dari kopi Indonesia menurun dan memberhentikan impor, Ketua Umum Gabungan Eksportir dan Industri Kopi Indonesia (Gaeki) Hutama Sigandhi mengatakan "Impor kopi kita, terutama robusta mayoritas datang dari Vietnam. Ketika harga kopi di negara tersebut setara dengan harga di negara kita, produsen pasti memilih menggunakan produk dalam negeri. Apalagi, kopi Vietnam kan kualitasnya di bawah kopi Indonesia" (DP, 2019).

Dalam hal ini, ekspor kopi Indonesia meningkat dan menekan harga kopi Indonesia. Namun dilain sisi, konsumsi produk dalam negeri meningkat yang membuat para penggemar kopi di Indonesia lebih memilih kopi Indonesia. Terlihat juga dalam faktor- faktor yang dituliskan pada bagian sebelumnya, kaum millennial sangat melekat dengan budaya minum kopi dan sering berkunjung ke coffeeshop. Dengan adanya aplikasi ini dikala pandemi, para penggemar kopi tetap dapat menemukan tempatnya untuk berinteraksi selain itu fakta yang ditulis sebelumnya yang menunjukkan kedekatan teknologi smartphone yang sangat menempel erat dengan generasi millennial. Di lain sisi, aplikasi ini belum pernah dibuat oleh pihak lain. Terdapat beberapa aplikasi yang sejenis tetapi hanya mengandung konten yang sangat terbatas. 2.3.4 Faktorusaha/jenis Usaha / jenis aplikasi yang serupa dengan aplikasi wadah interaksi penggemar kopi ini belum ada, namun ada salah satu fitur dari aplikasi wadah interaksi penggemar kopi ini memiliki kemiripan dengan aplikasi sebelumya, nama aplikasi tersebut adalah Brew Timer: Find coffee recipes\&Make great coffee. Aplikasi ini memudahkan pengguna untuk menemukan resep metode menyeduh milik para penggemar kopi lain sehingga dapat saling mencoba resep dan belajar. Namun kelemahan dari aplikasi ini,tidak adanya fitur untuk komentar dan lain sebagainya sehingga tidak ada interaksi yang terbangun dalam interaksi tersebut.

\section{Analisa Pasar}

Dalam Analisa pasar yang dilakukan, penulis membagikan survei kepada responden yang meminum kopi namun tidak memiliki komunitas. Penulis ingin melihat hasil minat dari perspektif luas "pengkonsumsi" kopi apakah mereka membutuhkan aplikasi wadah interaksi penggemar kopi online. Namun sebelum memasuki bagian tersebut, penulis melakukan survei kepada 60 responden generasi millennial yang menunjukkan persentase dari kegemaran minum kopi pada generasi millennial.

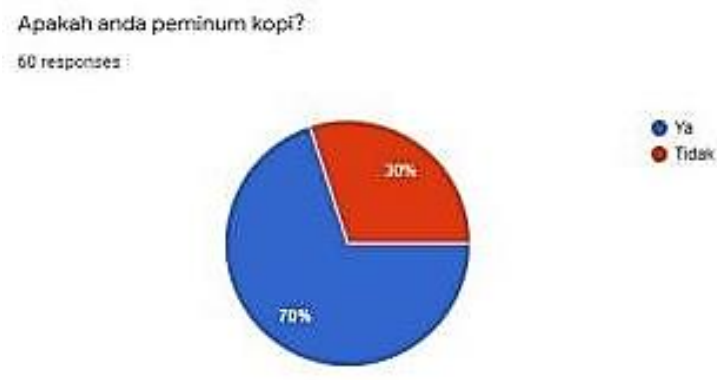

Gambar 2. Data Millennial Mengkonsumsi Kopi

Terlihat pada hasil survey dari 60 responden, 42 responden adalah generasi millennial yang sering mengkonsumsi kopi. Dari data tersebut dinyatakan Sebagian besar generasi millennial gemar mengkonsumsi kopi.

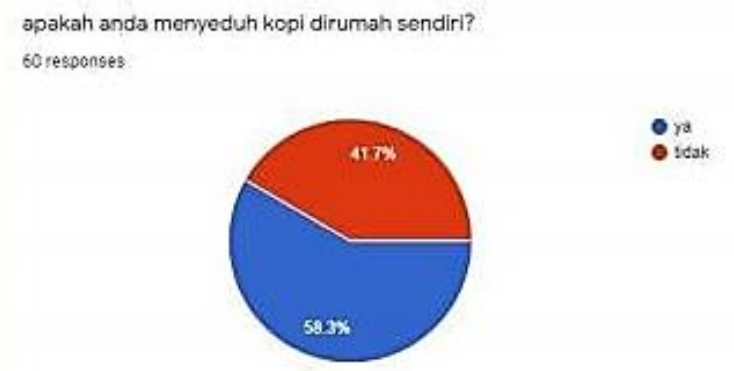

Gambar 3. Data Millennial Menyeduh Kopi di Rumah

Dalam data menyeduh kopi di rumah, 35 dari 60 responden memiliki kebiasaan untuk menyeduh kopi di rumah, dalam Analisa ini menunjukkan potensi kepada salah satu fitur dalam aplikasi penulis dalam fitur "resep menyeduh" sehingga memudahkan pengguna untuk melakukan seduh sendiri di rumah dan 
eksplorasi lebih banyak.

apakah anda mengetahui third wave coffee / specialty coffee? 60 rosponses

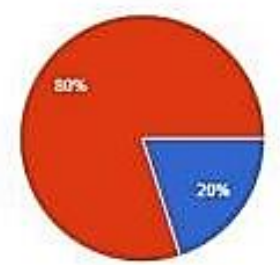

o yo

Gambar 4. Data Pemahaman Millennial Tentang Third Wave Coffee

Dalam grafik pie yang ditampilkan, terbukti bahwa masih sedikit generasi milenial pengkonsumsi kopi mengenal dan mengetahui tentang third wave coffee dimana potensi aplikasi ini lebih mengarah kepada revolusi kopi third wave. Dan dalam Analisa grafik ini, bisa dikaitkan dengan persentase jenis konsumsi kopi yang millennial konsumsi, yaitu kopi kekinian dengancampuran aneka sirup, bubuk dan bahan tambahan lain.

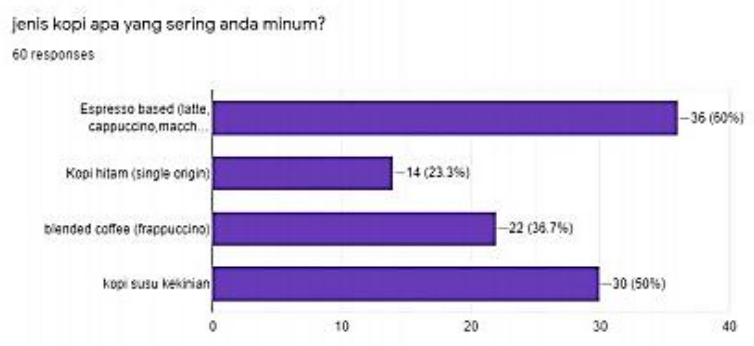

Gambar 5. Data Jenis Kopi yang Sering Dikonsumsi

Dalam grafik ini terlihat dari 60 responden, 30 orang dari 60 menyukai kopi susu kekinian dan 36 dari 60 orang menyukasi espresso based. Sedangkan tampak jelas hanya 14 orang dari 60 orang yang memilih kopi single origin dimana kopi jenis ini lebih sering dijadikan object untuk penggemar kopi melakukan eksplorasi pada sebuah varietas, asal, dan cita rasa kopi, atau lebih mudahnya sebagai objek umum untuk specialty coffee dan tanda lambang sebuah generasi third wave coffee.

\section{Usulan Pemecahan Masalah dan Positioning}

Tampak pada hasil Analisa pasar dan data yang dikumpulkan, terlihat bahwa target (sebagian besar) memiliki kegemaran dalam minum kopi, Data juga menunjukkan bahwa (persentase) adalah konsumenyang menyeduh kopi sendiri dirumah, sehingga fitur brewing recipe yang ditawarkan dalam aplikasi wadah interaksi penggemar kopi online ini sangat sesuai dengan target. Selain itu untuk target yang lebihspesifik, penggemar kopi perwakilan dari narasumberyang penulis wawancarai, rian merasa aplikasi ini sangat dibutuhkan dan diperlukan dikarenakan belum adanya aplikasi serupa yang dapat menampung interaksi para penggemar kopi di Indonesia. Bahkan narasumber juga sangat tertarik dan menyarankan untuk ekspansi fitur lebih spesifik dan lebih luas lagi untuk wadah interaksi ini sehingga informasi dalam industri kopi mulai dari proses, alat, dan lain sebagainya dapat tersebar lebih mudah dan luas. Dan penulis menyimpulkan dari seluruh wawancara bersama narasumber bahwa aplikasi ini merupakan pusat utama interaksi dan informasi online dalam dunia kopi. Hal itu juga dikatakan oleh teman dari narasumber setelah sesi wawancara selesai dan mengatakan "perlu sih ini, jadi pusat info dan sharing menarik lo". Dengan banyaknya manfaat yang dimiliki aplikasi ini bagi penggemar kopi, penulis ingin memposisikan aplikasi ini sebagai "survival kit penggemar kopi” dimana para penggemar kopi "harus" memiliki aplikasi ini sebagai panduan hidupnya di dunia kopi.

\section{Analisa Hasil Wawancara}

Analisa data juga dilakukan dalam hasil wawancara bersama narasumber yang bernama Rian. Narasumber memiliki peranan sebagai roaster dan juga barista pada sebuah coffee shop. Pengalaman narasumber terhadap kopi dimulai pada awal tahun 2012 hingga saat ini. dalam hasil wawancara, disimpulkan narasumber memiliki sebuah komunitas kecil di Surabaya dan hanya sebatas di Surabaya, narasumber juga mengatakan bahwa masih banyak pendatang di coffee shop belum mengetahui specialtycoffee/third wave coffee, selain itu narasumber menunjukkan bahwa banyak pengunjung yang datang dan saling bertukar pendapat dengan barista di coffeeshop karena ingin belajar kopi lebih dalam dan ada yang hanya ingin sekedar mengetahui. Narasumber berkata hal tersebut sering terjadi disebabkan kebosanan konsumen kopi terhadap pemesanan kopi secara online sehingga tidak ada teman yang dapat diajak berbincang dan bertukar pendapat. Bahkan ada pengalaman yang menarik bagi narasumber dikarenakan konsumen yang tidak pernah mengkonsumsi kopi namun penggemar rokok, konsumen tersebut tidak biasa dalam konsumsi kopi dan datang untuk bertanya dan konsultasi, setelah itukonsumen tersebut menjadi paham dengan kopi dan mengetahui ada kopi yang cocok untuknya. 
Narasumber bercerita bahwa sulit untuk berkomunikasi Kembali bersama teman komunitas, dikarenakan tidak ada wadah secara online dan tidak dapat bertemu tatap muka secara fisik dikarenakan kondisi saat ini. bahkan komunitas dari narasumber hanya dapat melakukan acara satu kali saja di tahun 2020 ini. dengan begitu narasumber merasa aplikasi yang dirancang oleh penulis dapat sangat membantu komunitas dan penggemar kopi di Indonesia karena dapat menjangkau seluruh penggemar kopi di Indonesia tanpa harus ada tatap muka fisik. Narasumber juga sempat menambahkan beberapa idedan poin penting dalam industri kopi yang diperlukan dalam rancangan aplikasi.

\section{Fitur}

\section{Home}

Memiliki isi posting-posting dari pengguna lain sehingga dapat saling bertukar informasi dan berinteraksi. Fitur ini merupakan fitur utama dalam aplikasi komunitas penggemar kopi di Indonesia sebagai wadah.

\section{Explore}

Memampukan pengguna untuk mencari dan menemukan berbagai informasi sesuai yang dicari melalui filter berdasarkan nama pengguna, judul posting yang terkait, dan title dari pengguna lain. Dalam fitur ini dapat membantu para pengguna dengan menemukan informasi yang ingin dipelajari dengan terkategorikan dan spesifik. fitur ini, sangat membantu dan menjadikan keunggulan aplikasi Kavi coffee app dibandingkan komunitas online yang menggunakan platform online umum seperti Instagram dan Facebook

\section{Post}

Fitur yang mengizinkan para penggunanya untuk berbagi cerita dan pengalaman yang dimilikinya tentang kopi. Pada fitur ini dapat membantu komunitaskopi di Indonesia dapat berkembang lebih mudah karena adanya pertukaran informasi dari berbagai pengguna dengan pengalaman yang berbeda.

\section{Activity}

Memiliki fungsi membantu pengguna untuk memantau interaksi dari pengguna lain yang merespon konten yang dibuatnya.

\section{Brew}

Fitur yang dapat membantu para pengguna untuk menjelajahi berbagai resep seduhan yang di- bagikan pada seluruh pengguna aplikasi Kavi coffee app.

\section{Konsep Usaha}

Dalam rancangan media interaktif wadah interaksi penggemar kopi online ini, dikategorikan sebagai usaha yang menawarkan dibidang jasa. Dikarenakan aplikasi ini menawarkan tempat untuk para penggemar kopi dapat melakukan interaksi berupa bertukar informasi, cerita, menambah teman dan lain sebagainya.

Untuk nama usaha pada aplikasi komunitas penggemarkopi online di ambil dari refrensi nama-nama yang berhubungan dekat dengan kopi. Kavi adalah nama yang ditentukan untuk aplikasi, nama Kavi sebelumnya belum pernah terdaftar untuk sebuah nama brand dan belum digunakan. Nama Kavi didapatkan dari pengejaan Bahasa inggris coffee namun dituliskan dengan pengejaan yang familiar dengan lidah Indonesia. Hal ini dibuat untuk mempermudah pengguna aplikasi yang telah di fokuskan kepada masyarakat Indonesia sehingga mudah mengeja nama brand. Selain itu, nama yang diberikan memiliki dua suku kata yang dapat membantu penghafalan nama brand lebih mudah.

Untuk mempertegas dari fungsi utama dan manfaat dari brand, Kavi memiliki keterangan bantuan "Coffeeapp" dan "coffee community and guide" hal ini ditujukan dikarenakan brand Kavi baru pertama kali hadir di masyarakat, sehingga diperlukan penjelasan nama brand dari Kavi.

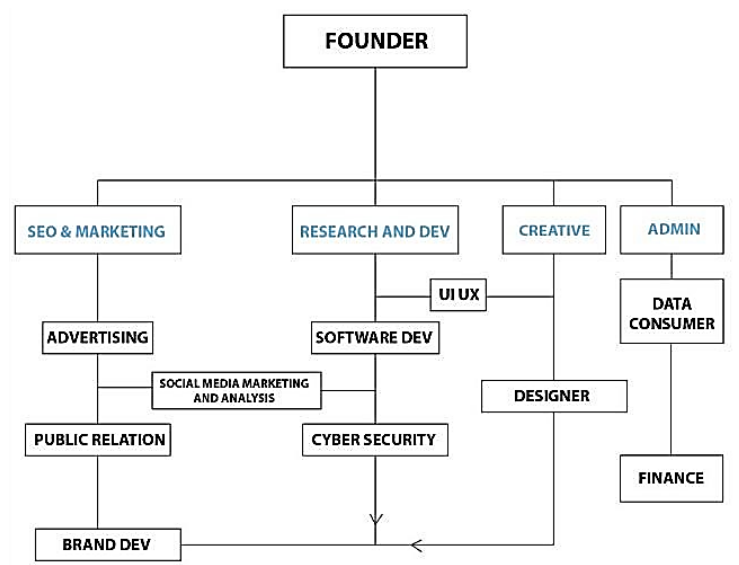

Gambar 6. Struktur PerusahaanKebaruan Produk

Dalam kebaruan produk, penulis telah melakukan analisa pada aplikasi-aplikasi yang berbasis onlinemaupun offline dan berfokus pada kopi, namun penulis hanya bisa menemukan 
aplikasi dengan fitur "brewing recipe" dimana para pengguna dapat membagikan danmelihat resep menyeduh seseorang. Selain itu ada juga aplikasi tentang spektrum rasa pada kopi dan penjelasan secara detail tentang rasa tersebut. Dalam aplikasi yang tidak berhubungan dengan kopi, namun memiliki fungsi yang serupa, dapat ditemukan pada Instagram, Kaskus, Facebook, dan lain sebagainya. Namun terdapat kelemahan yang ditemukan oleh penulis yaitu topik yang terlalu luas dan tidak segmented. Sehingga membuat para users kesulitan untuk mendapatkan topik dan pembahasan yang rinci tentang dunia kopi. Selain itu fitur dalam aplikasi tersebut jelas terbatas untuk pengguna kopi dikarenakan media yang digunakan difokuskan untuk sosial media secara universal. Sehingga dapat disimpulkan bahwa aplikasi yang tersegmentasi untuk penggemar kopi dengan fitur seperti sosial media dikarenakan aplikasi ini adalah wadah interaksi, masih belum ada dan masih sangat baru. Hal ini juga didukung oleh pertanyaan penulis untuk narasumber tentang aplikasi yang serupa dan narasumber menjawab bahwa aplikasi seperti ini belum ada sebelumnya.

Brand merupakan dentitas yang ingin ditonjolkan. Identitas Kavi Coffeeapps yang akan ditonjolkan untuk logo dan corporate identitynya adalah berkesan Homy, nyaman dan universal sebagaimana Kavi ingin memberikan rasa komunitas kopi ini menjadi tempat yang nyaman untuk bertukar pengalaman dan cerita. design minimalis dan berwarna soft membawa kesan yang modern dan professional sehingga membuat Kavi coffee apps menjadi lebih future proof. Penentuan identitas yang ditonjolkan bertujuan agar target dari pengguna generasi milenial tetap merasa nyaman dalam menggunakan aplikasi, mudah dan juga simple. Selain itu dengan konsep yang universal dari brand ini, memudahkan brand Kavi coffee apps dapat berbaur dengan brand dalam industry food and beverage lain, yang dimana memungkinkan brand Kavi coffee apps dapat berkolaborasi dengan brand lain.

Untuk menampilkan identitas brand yang bergerak dalam aplikasi kopi dan komunitas maka bentuk ikonik yang dipilih adalah ikon dari biji kopi yang menjadi penjelasan bahwa brand berjalan pada lingkup kopi. Selain itu untuk menampilkan sarana media yang digunakan adalah aplikasi yang berkategorikan social media, dipilih ikon dari symbol percakapan atau diskusi yang berupa buble chat. Beberapa dalam unsur brand dipilih juga ikon dan simbol yang telah di simplified yang berhubungan dengan beragam alat kopi. Semua unsur tersebut digabungkan dan dijadikan kesatuan yang simple, profesional, nyaman dan universal.

Untuk jenis font atau tipografi yang dipilih adalah yang mampu menunjukkan kesan sederhana, mudah dibaca, profesional. Pemilihan ini bertujuan untuk mempertegas pesan yang brand ingin sampaikan kepada penggunanya. Dalam unsur-unsur tersebut, font yang dipilih untuk brand Kavi coffee apps adalahMonsterrat dan juga Century gothic.

$\begin{array}{ll}\text { Kavi Coffee Apps } & \text { Monsterrat } \\ \text { Kavi Coffee Apps } & \text { Monsterrat medium } \\ \text { Kavi Coffee Apps } & \text { Monsterrat bold } \\ \text { Kavi Coffee Apps } & \text { Century Gothic }\end{array}$

Dalam brand Kavi coffee apps ingin memberikan kesan yang profesional dan juga sederhana dan nyaman. Dalam pemilihan tersebut Kavi coffee apps ingin menjadi universal dan hadir dalam setiap kalangan penggemar kopi. Tone and manner yang tenang, homy, dan juga profesional ingin menegaskan bahwa keseriusan brand dalam menampung dan menaungi penggunanya sebagai wadah penggemar kopi. Desain yang minimalist dengan penjelasan teksyang singkat, dan jelas menjadi guide pada brand yang bertujuan memberikan kenyamanan penggunaan selain itu memberikan pesan universal yang dapat berlaku pada jangka Panjang apabila brand berhasil melakukan kolaborasi dengan ber-bagai brand kopi maupun industry food and beverage lainnya.

Pemilihan warna pada brand Kavi coffee apps adalahwarna biru dan juga emas. Pemilihan warna aini ditujukan agar Kavi coffee apps memiliki ciri khas dan keunikan tersendiri dibandingkan dengan kompetitor dalam aplikasi kopi dan juga dalam bisniskopi di Indonesia. Warna biru muda yang digunakan menunjukkan pesan trust dan juga universal, selain itu warna biru muda yang digunakan memberikan pesan profesional tetapi homy dan juga calm. Untuk warna yang kedua sebagai unsur pendukung menggunakan warna coklat-emas yang melambangkan premium dan kualitas yang baik untuk penggunanya, serta memberikan kenyamanan dalam bertumbuh di komunitas bagi setiap penggunanya. Warna yang terakhir sebagai warna untuk keperluan desain dan kebutuhan lainnya jika menggunakan warna putih menggunakan warna pearl white sebagai dasar acuan warna putih untuk brand Kavi coffee apps. 


\begin{tabular}{|c|c|}
\hline $\begin{array}{l}\text { R: } 34 \\
\text { C: } 146 \\
\text { B: } 221\end{array}$ & $\begin{array}{l}\text { C: } 74 \quad Y: 0 \\
\text { M:32 K:O }\end{array}$ \\
\hline $\begin{array}{l}\text { R: } 178 \\
\text { C: } 125 \\
\text { B: } 48\end{array}$ & $\begin{array}{lll}\text { C: } 27 & Y: 96 \\
\text { M:51 } & \text { K:8 }\end{array}$ \\
\hline $\begin{array}{l}\text { R: } 244 \\
\text { : } 244 \\
\text { B: } 244\end{array}$ & $\begin{array}{ll}C: 3 & Y: 2 \\
M: 2 & K: 0\end{array}$ \\
\hline
\end{tabular}

Gambar 7. Warna pada Brand Kavi Coffee App

Dengan ikon yang disederhanakan dan dikombinasi, membentuk sebuah dua balok dialog dengan siluet garis kopi, sehingga dalam satu bentuk tersebut memiliki dua ikon sekaligus yaitu balok dialog yang saling berlawanan menandakan adanya interaksi antar pengguna dan juga ikon kopi yang disederhanakan.

\section{Pengembangan Ide Logo}

Pengolahan bentuk ikonik menjadi simbolik dengan bentuk ikonik yang digunakan adalah bentuk ikonik yang memiliki keseragaman dengan identitas dan bidang dari brand Kavi coffee apps. Dari bentuk dasar logo, refrensi ikon diambil dari alat seduh, bahan seduh, dan juga biji kopi. Dan untuk wujud sosial media, refrensi di ambil dari ikon dialog percakapan online yang menunjukkan adanya komunikasi 2 arah atau lebih secara online.

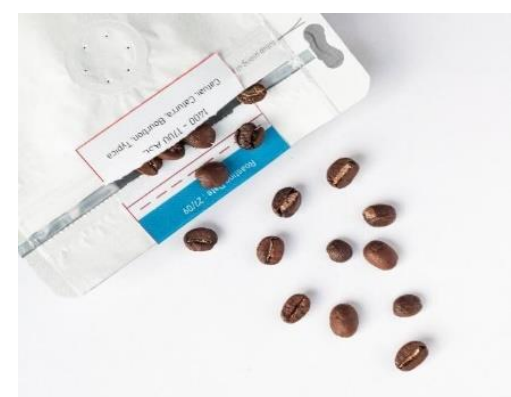

Gambar 8. Biji Kopi sebagai Refrensi Logo

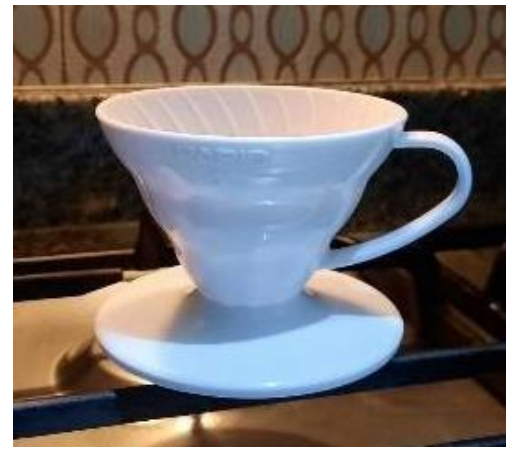

Gambar 9. V60 Dripper Sebagai Refrensi Logo

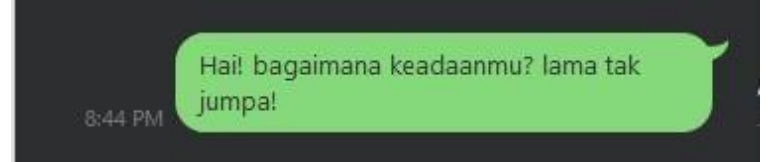

Gambar 10. Visual Dialog sebagai Refrensi Logo Final

Dengan ikon yang disederhanakan dan dikombinasi, membentuk sebuah dua balok dialog dengan siluet garis kopi, sehingga dalam satu bentuk tersebut memiliki dua ikon sekaligus yaitu balok dialog yang saling berlawanan dimana menandakan adanya interaksi antar pengguna dan juga ikon kopi yang disederhanakan.

Logo dengan icon yang memiliki garis naif memberikan kesan santai dan fun yang memberikan kesan homy. Dengan pemilihan warna biru terang danjuga coklat-emas dapat menekankan garis yang naif pada logo terkesan profesional dan terpercaya walaupun terkesan santai. Hal yang diterapkan pada logo sesuai dengan tujuan dari aplikasi Kavi Coffee App yang ingin memberikan komunitas kopi online yang sehat, baik, fun, universal, bisa untuk siapapun namun professional.

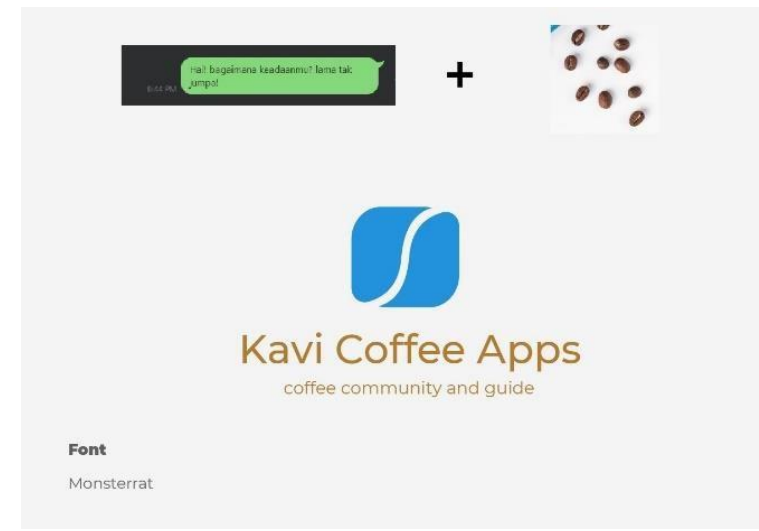

Gambar 11. Hasil Akhir Logo dengan Refrensi Ide

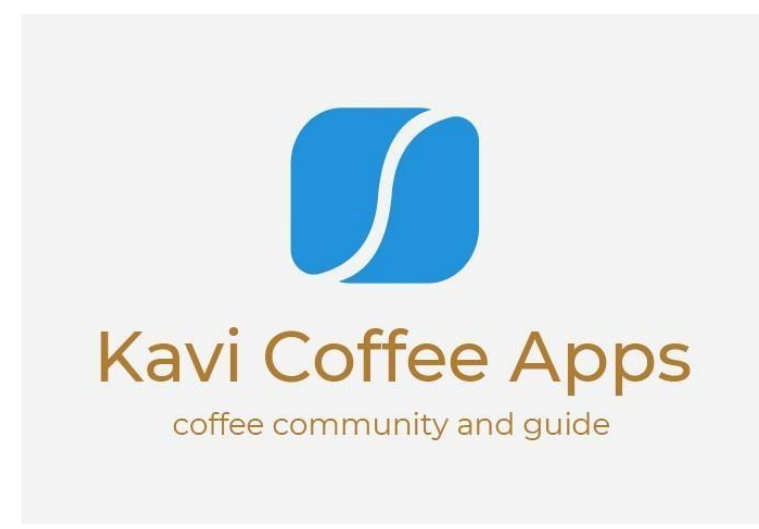

Gambar 12. Hasil Akhir Logo 

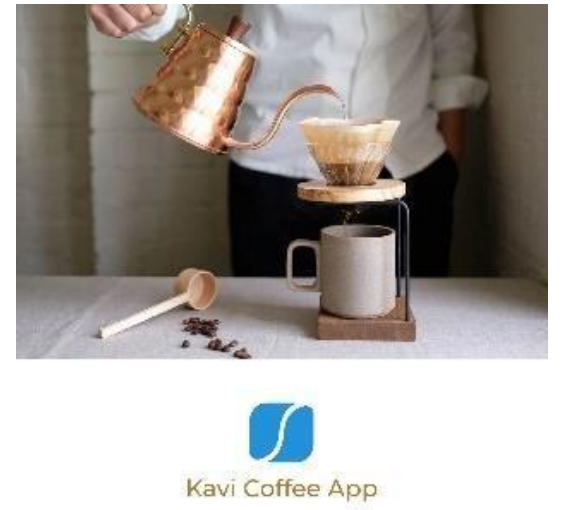

ABOUT US

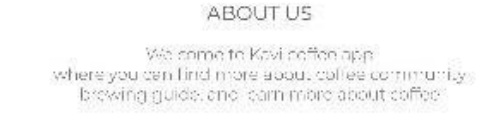

SION IN

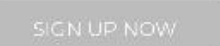

Gambar 14. Tampilan Awal Aplikasi

Tampilan pada aplikasi Kavi coffee app, memiliki tone and manner sesuai dengan gaya brand yang telah ditentukan sebelumnya.

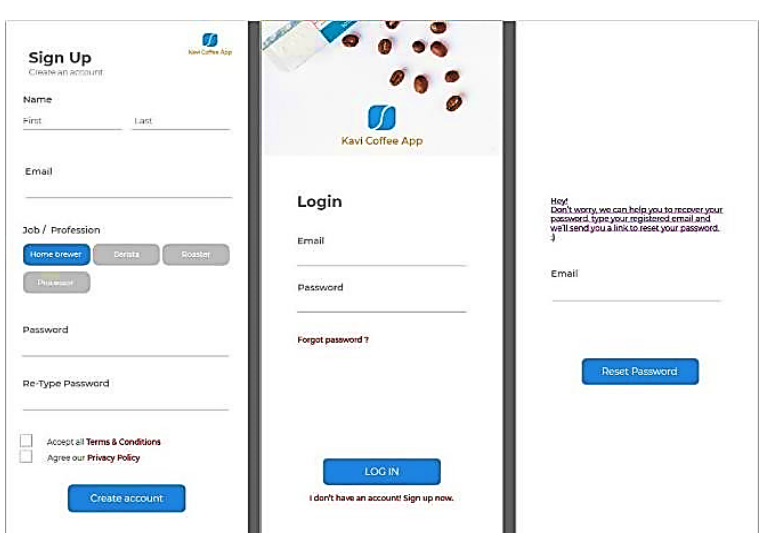

Gambar 15. Tampilan Fitur Login / Sign Up

Penggunaan eksplorasi memudahkan pengguna untuk mendapatkan informasi yang ingin dicari. Informasi yang dapat dicari pada fitur ini beragam, mulai dari pencarian user lain dengan melakukan input ID, mencari sebuah topik yang dapat ditelusuri melalui judul yang terkait, mencari genre atau kategori dengan mengimbuhkan symbol '\#” sebelum mencari kategori dan yang terakhir memiliki fitur untuk mencari postingyang terkait dengan title/role pengunggah sehingga memudahkan pengguna untuk mencari atau belajarmateri yang dibagikan oleh user dengan title yang sama.
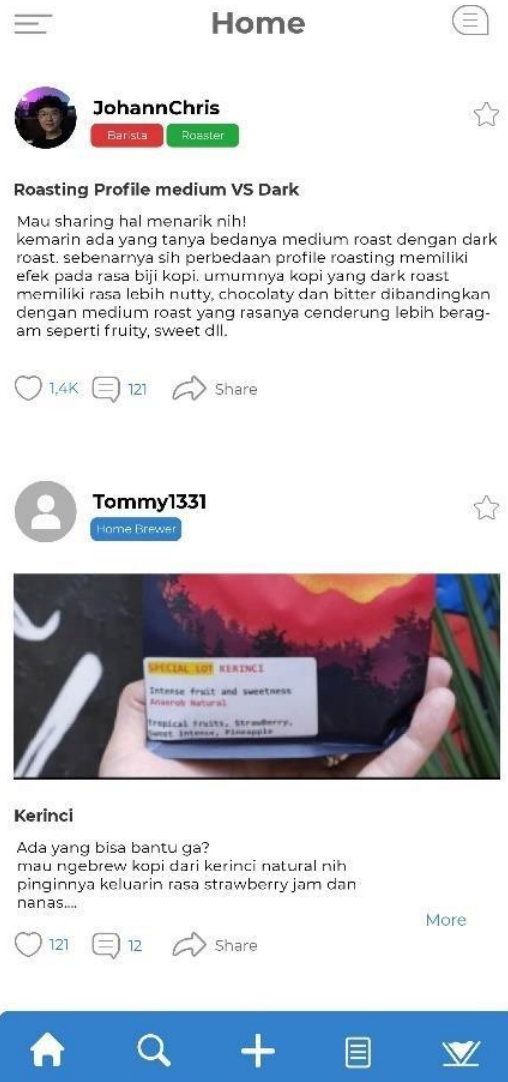

Gambar 16. Tampilan Fitur Home

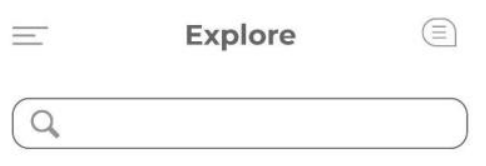

You can find more post specifically g title, username or pro
sion at search bar

\section{A $Q+$ 目 $\quad$}

Gambar 17. Tampilan Fitur Explore

Untuk fitur tambahan lebih lanjut pada bagian explore,pengguna dapat melakukan pencarian pada sebuah produk kopi yang dijual oleh antar 
pengguna, dimana fitur ini akan terhubung langsung oleh fitur shop yang pada waktu ke depan ditambahkan pada aplikasi.
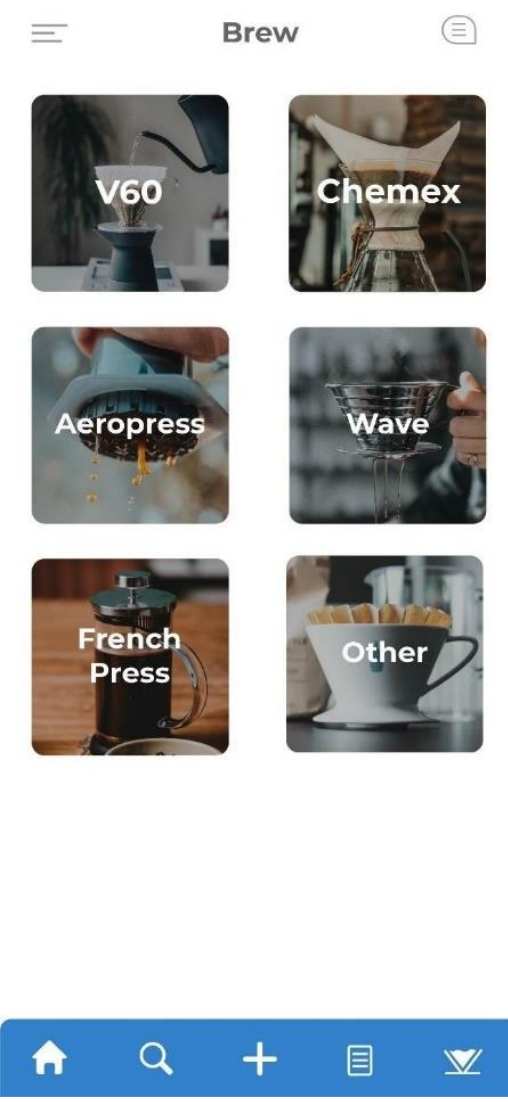

Gambar 18. Tampilan Fitur Brew

Fitur yang dapat membantu para pengguna untuk menjelajahi berbagai resep seduhan yang dibagikan pada seluruh pengguna. Fitur ini memiliki beberapa fitur tambahan yang dapat mempermudah pengguna untuk berinteraksi langsung dengan pembuat resep. Terdapat fitur like, comment, share, dan save.

\section{Kesimpulan}

Dengan data yang telah dikumpulkan, penulis menyimpulkan bahwa tidak semua peminum kopi memiliki komunitas. Kehadiran generasi third wave coffee membuat budaya atau komunitas dan penggemar kopi terlahir di Indonesia namun disayangkan dalam dunia kopi yang penuh kekompleksan dan proses yang panjang, sangat susah apabila tidak ada wadah yang dapat menampung informasi tersebut secara efisien dan mudah. Selain itu, faktor eksternal yang baru-baru muncul di Indonesia yaitu pandemi COVID-19 menyebabkan kesulitan tersebut semakin merepotkan. Dengan dilihatnya masalah dan penarikan kesimpulan dari pengumpulan data tersebut, penulis memiliki solusi dalam permasalahan yang terjadi.
Dengan pembuatan Media Interaktif Wadah Penggemar Kopi ber-platform online, penulis dapat memberikan jawaban untuk komunitas dan para penggemar kopi agar memiliki wadah sebagai interaksi dan bertumbuh bersama. Kavi coffee app merupakan aplikasi media sosial yang ter-segmented untuk para penggemar kopi.

\section{Daftar Pustaka}

(2019, February 14). Pertumbuhan Industri Kopi DiharapkanDorong Lahirnya Lebih Banyak Petani Kopi Milenial.

2021, Konsumsi Kopi Indonesia Diprediksi Mencapai 370 Ribu Ton|Databoks. (2018). https://databoks.katadata.co.id/datapublish/ 2018/07/31/2021konsumsikopi-indonesiadiprediksi-mencapai-370-ribu-ton

Aizeindra, Y. (2018,). 5 Tipe Green Coffee Buyer Ketika Membeli Biji Kopi. Majalah Otten Coffee. https://majalah.ottencoffee.co.id/5tipe-green-coffee-buyer-ketika-membelibijikopi/

Aizeindra, Y. (2019a, June 23). Seperti Apa Sebenarnya Specialty Coffee. Majalah Otten Coffee. https://majalah.ottencoffee.co.id/sepertiapa sebenarnya-specialty-coffee/

Aizeindra, Y. (2019b, December 13). Coffee Trip: Tips Petik Kopi Dari Petani Kopi Mandailing. Majalah Otten Coffee. https:/majalah.ottencoffee.co.id/ tips-petik-kopi/

Andani, M. (2020, January 10). Nongkrong Sambil Ngopi Jadi Tren Anak Muda Masa Kini. RMOLSUMUT. https://www.rmolsumut.id/ nongkrong-sambilngopijadi-tren-anakmuda-masa-kini

Anjarwati, J. (2020, February 2). Media Sosial: Pengertian, Jenis, Fungsi, dan Contoh. FA Tekno. https://tekno.foresteract.com/mediasosial/antaranews.com.

AntaraNews.https://www.antaranews.com/beri ta/798139/pertumbuhan-industrikopidiharapkandorong-lahirnya-lebihbanyak-petani-kopi-milenial

Aplikasi Fore Coffee Trending di App Store dan Play Store, Apa sih itu? (2019, October 30). https://www.mainmain.id/r/3662/aplikasifore-coffee-trending-diapp-store-dan-playstore-apa-sih-itu

Cahyani, D. R. (2019). Cocok untukMillenial, Bisnis Kopi Cukup Bermodal Rp 17 JutaBisnis Tempo.co. https://bisnis.tempo.co/ read/1245208/cocok-untuk-millenial-bisniskopi-cukup bermodal-rp-17-juta

CNN, I. (2020). Pengguna Aplikasi Video Conference Imbas WFH di RI Meningkat. Teknologi. https://www.cnnindonesia.com/teknologi/20 200323074557-213-485895/pengguna- 
aplikasi-video-conference-imbas-wfh-di-rimeningkat

Colonna-Dashwood, M., \& Jay, T. (2017). The Coffee Dictionary: An A--Z of Coffee, from Growing \& Roasting to Brewing \& Tasting. Chronicle Books.

Devvany, G., Ivana, S.H. (2017). Kajian Budaya Minum Kopi Indonesia. Retrieved from: https://trijurnal.lemlit.trisakti.ac.id/dimensi /article/view/1785

Dhir, R. (2019, June 25). How Interactive Media Works. Investopedia. https://www.investopedia.com/ terms/i/interactive-media.asp

DP, Yustinus A. (2019). Penyebab Utama Anjloknya Harga Kopi Indonesia | Ekonomi. Bisnis.Com. https://ekonomi.bisnis.com/read/20190717/1 2/1125213/penyebab-utama-anjloknyaharga-kopi-indonesia

Freeman, J., Freeman, C., Duggan, T., McLachlan, C., \& Ott, M. (2012).The Blue Bottle Craft of Coffee: Growing, Roasting, and Drinking, with Recipes (1st ed). Ten Speed Press.

GAIN. (2019). Indonesia: Coffee Semi-annual | USDA Foreign Agricultural Service. https://www.fas.usda.gov/data/indonesiacoffee-semi-annual-5

Guntoro. (2020, September 17). $\sqrt{ }$ Apa itu Aplikasi Mobile? Inilah Ulasan Lengkapnya! Badoy Studio. https://badoystudio.com/aplikasi-mobile/

Handayani, I. (2018, March 15). Kopi Jadi Bagian Gaya Hidup Kaum Milenial. beritasatu.com. https://www.beritasatu.com/feri-awan hidayat/archive/483382/kopi-jadi-bagiangaya-hidup-kaum-milenial

Herlangga, K. G. D. (2016, July 3). Virtual Reality dan Perkembangannya. CodePolitan.Com. https://www.codepolitan.com/virtualreality-dan perkembangannya

Herlyana, E. (2012). Fenomena Coffee Shop Sebagai Gejala Gaya Hidup Baru Kaum Muda. Retrieved from Universitas Islam Negeri Sunan Kalijaga Yogyakarta: https://www.google.com/url?sa=t\&rct=j\&q= \&esrc $=$ s\&source $=$ web\&cd $=$ \&ved=2ahUKEwic0tGZvKnsAhWHIbcAHU oyDDoQFjAAegQIBhAC\&url=htt p $\% 3 \mathrm{~A} \% 2 \mathrm{~F} \% 2 \mathrm{Fejournal.uinsuka.ac.id} \% 2 \mathrm{Fad}$ ab\% 2 Fthaqafiyyat $\% 2$ Farticle $\%$ $2 \mathrm{Fdownload} \% 2 \mathrm{~F} 43 \% 2 \mathrm{~F} 42 \&$ usg $=$ AOvVaw2ptAt23tHZ47YU4LQlhcRR

Hidayah, Manarul. (2020). Sempat Diremehkan, 3 Pekerjaan ini Malah Semakin Diminati. https://www.rancah.com/lifestyle/15517/sempat-diremehkan-3pekerjaan-ini-malah-semakin-diminati/

Holl, Konstantin, \& Elberzhager, F. (2019). Mobile Application - An Overview Science Direct Topics. https://www.sciencedirect.com/topics/compu ter science/mobile-application

Indozone. (2019, October 8). Kopi, Jadi Ladang Bisnis yang Menjanjikan Bagi Milenial. https://www.indozone.id/news/jzsyRl/kopijadi-ladang-bisnis-yang-menjanjikan-bagimilenial

JawaPos.com. (2019). Jadi TongkronganAnakAnak Millenial, Harus Rajin Bikin Inovasi Produk. https://radarbali.jawapos.com/read/2019/12/ 01/168320/jadi-tongkrongan-anak-anakmillenial-harus-rajin-bikin-inovasi-produk

Jogiyanto, H. M. (2005). Analisa dan Desain Sistem Informasi Pendekatan Terstruktur Teori dan Aplikasi Bisnis. Yogyakarta: CV. Andi Offset.

Kasapakis, V., \& Gavalas, D. (2015). Pervasive Gaming: Status, Trends and Design Principles. Retrieved from Department of Cultural Technology and Communication University of the Aegean, Mytilene, Greece : http://portal.lib.aegean.gr/

Keepo.me. (2018, November 16). Café Bagi Milenial, Lebih dari Sekadar Tempat Mengisi Perut! | Keepo.me. LINE TODAY. https://today.line.me/id/v2/article/MQwEya

Kramer, W. (2000). What Is A Game? http://www.thegamesjournal.com/articles/W hatIsaGame.shtml

Kurniawan, K. (2019). Pengertian Website Lengkap 2020: Definisi, Jenis, Manfaat. Projasaweb. https://projasaweb.com/pengertian-website/

Linda. (2020, June 26). Yuk Kenali Pengertian Teknologi Virtual Reality (VR). Carisinyal. https://carisinyal.com/teknologi-virtualreality/

Masdakaty, Y.(2015, November 3). Mengenal MacamMacam Proses Pengolahan Kopi. Majalah Otten Coffee. https://majalah.ottencoffee.co.id/mengenalmacam-macamproses-kopi/

Morel, G. (2015). Linear vs. Non-Linear Television. https://www.linkedin.com/pulse/linear-vsnon-linear-television-guillaume-morel

Mubarok, I. (2018, April 11). Memaksimalkan Media Sosial untuk Bisnis Online. Niagahoster Blog. https://www.niagahoster.co.id/blog/mediasosial untuk-bisnis/

Mustofa, R.H. (2019, January 22). "The Third Wave Coffee" Halamanall — Kompasiana.com. https://www.kompasiana.com/rochman_hadi /5c4616df677ffb590f236758/thethird-wavecoffee?page $=$ all

Nurhanisah, Yuli. (2019). Yuk, Kenalan dengan Millenial Indonesia! | Indonesia Baik. http://indonesiabaik.id/infografis/yukkenalan-dengan-millenialindonesia

Nurikhsan, F., Indrianie, W.S., \& Safitri, D. (2019). Fenomena Coffee Shop di Kalangan Konsumen Remaja. Widya Komunika. 9(2). 
Pengaruh Teknologi Digital pada Industri Kuliner. (2019, May 10). https://highlight.id/pengaruhteknologi-digital-pada-industrikuliner/

Radiegtya, W. E. (2018, March 29). 3 Teknologi yang Terbukti Handal untuk Membangun Aplikasi Mobile Multi Platform. Medium. https://medium.com/@radiegtya/3-teknologiyang-terbukti-handal-untuk-membangunaplikasi-mobile-multi-platform$1001 \mathrm{ca} 69 \mathrm{e} 4 \mathrm{ba}$

Ramadhan, B. (2020, April 8). Data Internet di Indonesia dan Perilakunya Tahun 2020. Medium. https://teknoia.com/data-internetdi-indonesia-dan-perilakunya 880c7bc7cd19

Riyadi, S. (2017, July 13). 27 Istilah Informasi Teknologi di Jagad Maya - Kompasiana.com. https://www.kompasiana.com/pipot/5966ed9 282386a14a322fc62/27-istilah-informasiteknologi-di-jagad-raya

Saffer, \& (n.d.). Designing for Interaction: Creating Innovative Application and Devices.

Satria. (2018, July 31). Milenial yang Rakus Kopi. Blog Kopi Paling Enak. http://kopikopikopi. com/milenial-rakus-kopi/

Setiawan, S. (2020, August 5). Pengertian Advertising - Periklanan, Tujuan, Fungsi, Manfaat, Dampak, Ciri, Komponen, Syarat. GuruPendidikan.Com.

https://www.gurupendidikan.co.id/pengertian -advertising/

Soekanto, S. (2002). Sosiologi: Suatu Pengantar. RajaGrafindo Persada.

Solikatun, Drajat, T.K., Argyo D. (2015). Perilaku Konsumsi Kopi Sebagai Budaya Masyarakat Konsumsi: Studi Fenomenologi pada Peminum Kopi di Kedai Kopi Kota Semarang. Retrieved from: https://jurnal.uns.ac.id/jas/article/view/17410

Somantri, I.Z. (2011). Hyakugo Sebagai Multimedia Interaktif Pembelajaran Kanji N5. Retrieved from: https://elib.unikom.ac.id/download.php?id=146806

Sutrisni, A. (2019, October 12). Interaksi Sosial: Pengertian, Syarat, Ciri, Jenis, dan Faktornya Halaman all-Kompas.com. https://www.kompas.com/skola/read/2019/1 2/10/161818569/interaksi-sosial-pengertiansyarat-ciri-jenis-dan-faktornya?page $=$ all

Toffin. (2020, July 12). Riset Toffin - Toffin. https://toffin.id/?p=2830
Trautman, E. (2018, July 12). Interactive Video: How to Keep The Attention of Your Audience. Kaltura. https://corp.kaltura.com/blog/interactivevideo-what-it-is-why-it-matters-and-why-itdoesnt-always-work/

Treisna, M. (2015, August 27). 6 Profesi Penting dalam Dunia Kopi. Majalah Otten Coffee. https://majalah.ottencoffee.co.id/6-profesipenting- dalam dunia-kopi/

Vosmeer, M., \& Schouten, B. (2014). Interactive Cinema: Engagement and Interaction Games \& Play Research Group, CREATE-IT Applied Research. Retrieved from Amsterdam University of Applied Sciences, Amsterdam, The Netherlands: https://www.amsterdamuas.com/research/p ublication s/publications.html

Vyond. (2020, February 3). Interactive Videos: 68 Best Examples We've Ever Seen Vyond. https://www.vyond.com/resources/interactiv e-video-examples/

What is a Mobile Application? - Definition from Techopedia. (2020). Techopedia.Com. http://www.techopedia.com/definition/2953/ mobile application-mobile-app

What is Application Software? - Definition from Techopedia. (2020). https://www.techopedia. com/definition/4224/application-software

Wijaya, Y. (2014, April 24). Pengertian Multimedia Interaktif. Blog Yoga Permana Wijaya. https://yogapermanawijaya.wordpress.com/20 14/04/24/pengertian-multimediainteraktif-2/

Wijayanti, S. (2020, June 27). 10 Ciri Dasar Generasi Millennial, Kamu TermasukGakNih? https://www.idntimes.com/life/inspiration/si ntawijayantid/10-ciri-dasar-generasimillennial-c1c2/9

Yolanda, V. (2020). Strategi Kedai Kopi untuk Bertahan Dikala Serangan Pandemik COVID-19! Journal. https://wia.id/journal/strategi-kedai-kopiuntuk-bertahan-dikala-seranganpandemik-covid-19/

Yuliandri, M. Triesna. (2015, August 6). Sejarah "First, Second and Third Wave Coffee." Majalah Otten Coffee. https://majalah.ottencoffee.co.id/ sejarah-first-second-and-third-wave-coffee/

Yusron. (2020). Pengertian Seni Adalah: Jenis dan Contoh-Contohnya [Lengkap]. Belajar Giat. https://belajargiat.id/seni/ 